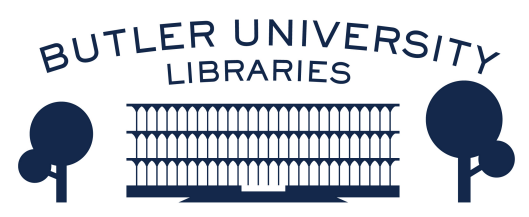

Journal of Hindu-Christian Studies

Volume 10

Article 9

January 1997

\title{
How Should Religion and Science be Creatively Related? A Christian Perspective
}

Robert John Russell

Follow this and additional works at: https://digitalcommons.butler.edu/jhcs

Part of the Religion Commons

\section{Recommended Citation}

Russell, Robert John (1997) "How Should Religion and Science be Creatively Related? A Christian Perspective," Journal of Hindu-Christian Studies: Vol. 10, Article 9.

Available at: https://doi.org/10.7825/2164-6279.1155

The Journal of Hindu-Christian Studies is a publication of the Society for Hindu-Christian Studies. The digital version is made available by Digital Commons @ Butler University. For questions about the Journal or the Society, please contact cbauman@butler.edu. For more information about Digital Commons @ Butler University, please contact digitalscholarship@butler.edu. 


\title{
How Should Religion and Science be Creatively Related? A Christian Perspective
}

\author{
Robert John Russell \\ Center for Theology and the Natural Sciences \\ The Graduate Theological Union, Berkeley
}

\section{A. Introduction: why relate religion and science?}

Each of us, Hindu and Christian alike, must seek each other's wisdom on one of the fundamental issues of our time: how should we relate religion and science? On the one hand, each of us has been formed and shaped by, and has inherited the wisdom and blessing of one of the world's great religions, and we should be committed to the dialogue between, and the mutual enrichment of, these religions. Through these religions, we are invited to practise compassion, to seek justice, to obtain enlightenment, to live in harmony with the natural world, and to find healing, forgiveness, and new life as we follow the paths of Hindu and Christian wisdom.

On the other hand, each of us, Hindu and Christian alike, also lives in a world culture where economic, political, ethical, social, and personal life is daily influenced or even determined by technology. From horses to cars to supersonic international air travel, from pre-historic drawings to photographs to television, from Pony Express to the telephone to the world-wide web, from coal to steam power to nuclear power, from wood to stone to iron, from the abacus to ENIAC I to the lap-top computer, from the astrolabe to Kepler's observatory to the Hubble Space Telescope, the history of humanity is the history of its radical transformation by technology. But technology works because of the unrivalled explanatory power and relentless, predictive virility of science, and science now provides a broad and mostly undistorted window on nature, including human nature. As representatives of the world's great religions, we are called by our people and by our inheritance to self-critically explore our beliefs in light of that science and what it tells us about our universe.

We now know more than any previous civilization about our physical and biological origins. Our species is living in a universe that has developed from an unthinkably hot, dense, and tiny state fifteen billion years ago - the hot Big Bang - to an overall present temperature of only three degrees above absolute zero. The visible universe alone is immense in size - over fifteen billion light years across. It is strewn with at least a hundred billion galaxies, each with several hundred billion stars. These are secondgeneration stars whose planetary systems, like our own, are made of the chemical elements produced by the supernovas of previous stars billions of years ago, stars which are now gone forever. On one planet of a minor main sequence star some three and a half billion years ago, organic molecules first appeared in primordial oceans bombarded with immense meteorological violence. Rapidly they developed first into primitive prokaryotic cells and then into eucaryotic cells. In the eons that followed, the instructions for life wrested through endless cycles of life and death and encoded in the intricate geometry of microscopic genes. In time multiple-celled organisms were added to single-celled ones, then life moved onto dry land and rapidly 
diversified into astonishing biological complexity. Through countless blind alleys, consciousness arose in diverse animal species. Primates, in particular, appeared just 60 million years ago. A million years ago, homo erectus emerged as the first hominid species to use fire. Over the past hundred thousand years, a particular hominid species, gifted with vastly increased brain size, succeeded in outliving or wiping out its competitors, and it soon was to multiply and cover the earth: homo sapiens. If life is almost inevitable given the right planetary conditions, stories like this may be common throughout the universe. Evidence from NASA now suggests that rudimentary life may have developed and become extinct on Mars. Is life present even now on Europa, the moon of Jupiter? We may soon have answers to these wondrous questions. ${ }^{1}$

Human life carries that ancient billion year old history in its genes, and in all aspects of genetic expression that we call individual personality and culture. Now it cannot be reduced to human nature to be religious: to hope, to experience depth, to love, to thirst for the infinite, perhaps to describe oneself as touched by that which utterly transcends oneself. How is it that a creature evolved from dust and water speaks words about spirit and eternity? Perhaps the immense discoveries of science can shed light on the religious dimension of being human. Christian theology played a contributing role in the rise of modern science in the West. Can it continue to offer creative insights to ongoing research in science? In turn, much of contemporary Christian theology has been shaped by the Newtonian world view, with its implicit reductionist materialism. What would our theology be like if it were thoroughly reformulated by an intense engagement with twentieth-century evolutionary science, physics, and Big Bang cosmology? Similarly, religion can offer to science a timely reminder about the humility needed in every human search for knowledge and for the wisdom to use that knowledge properly. And clearly the global issues raised by medicine, energy, communications, genetics, and the environment demand the finest wisdom of our diverse religious traditions. We cannot but respond if we are to maintain our integrity.

\section{B. Two key theological issues in light of contemporary science ${ }^{2}$}

1. Creation and design: Is the universe fine-tuned by God for life?

The Anthropic Principle has received a great deal of attention ${ }^{3}$ in scientific as well as in theological circles. Over the past two decades, scientists have discovered that the constants of nature, such as the speed of light, Planck's constant, or the strength of the fundamental physical forces, seem finetuned for life in this sense: had they been even slightly different, our universe would have been entirely incompatible with the evolution of sentient life on planets like earth. Life can only evolve if the right planetary and stellar circumstances are available. If these fundamental constants had been different by even one part per million, our universe would have been entirely lifeless forever. In this sense, life and mind did not "just happen", they are not just an extremely rare and essentially foreign feature of a predominantly inhospitable, inanimate universe. Instead the universe can be seen as "anthropic", that is, as one which teems with life, one in which life and mind are "at home", as essential parts of our universe. But then the question becomes "Why?". Of all the universes that could exist, why does the actual universe fit precisely the requirements for life and consciousness? Is the universe fine-tuned purposefully by God to allow for the evolution of sentient creatures capable of entering into communion with God?

Again, the extreme positions taken are irrelevance and direct support. The irrelevance response usually takes the form of a "many worlds" scenario which reasons 
away as only apparent the fine-tuning of the universe. There may be an endless supply of universes instantiating every possible value for the constants of nature. Naturally evolution will work to produce life in those universes which happen to be consistent with it. But what then could produce all these universes? One answer is inflation, a manyworlds scenario in which all these universes are distinct but connected domains of a single mega-universe. A more radical genre of many-worlds scenario arises with quantum gravity, where daughter universes separate off from the parent universe. Both scenarios have been criticized, though: are "many-worlds" scenarios subject to verification? should we conclude that "many worlds" exist simply because the laws and constants of nature can be varied formally? ${ }^{4}$

The direct argument, on the other hand, is that the best explanation of the fit between the laws and constants of nature and the requirements for life is that this is the design of God working purposefully, not within nature as Paley imagined but with the universe as a whole. In my opinion this argument runs the risk of conflating theology and science by ignoring their intrinsic differences. ${ }^{5}$ Moreover in its rush to dismiss the many-worlds arguments, it does not take seriously the valuable insights implicit within them.

My own view attempts to take these insights into account and can be summarized briefly $^{6}$ : I believe that both design and many-worlds contain a piece of the truth behind the theological conviction that the universe and, in turn, life and self-conscious free agency, are the creations of God. In essence, underlying the point/counterpoint format of the many-worlds versus the design arguments is an interplay between the basic philosophical categories of contingency and necessity, and it is here that the theological insight awaits us. However they are generated - whether by inflation or by quantum cosmology, in which our universe is part of an infinite set of universes - the existence of "many worlds" tends to explain away the contingency of our fine-tuned world. If many universes actually exist with every possible value for the constants of nature, those consistent with life will occur necessarily. But this, in turn, raises the question of a deeper form of contingency in the many-worlds argument: why are all these universes governed by the same laws? Perhaps the laws of nature, and not just the constants, are fine-tuned and point to God as the cosmic designer? Again one can construct a many-worlds response in which all possible laws of nature occur. Yet again one can point to contingency now at the level of the laws of nature: why do all these universes exemplifying all possible laws all obey the same kind of logic? Do we at last find an argument for God as the designer of logic? Once again, the point/counterpoint formula continues, but now at an even higher level of abstraction, and so on. Does the process of abstraction end, and if so, why, or does it continue indefinitely, and again if so, why? Moreover, even if there are an infinity of actual universes, the existence of at least one - ours - in which life can evolve underscores the meaningfulness of life. Like an oasis in a vast desert, a real universe with life captures our attention and provides a clue to the existence of the universe itself.

In short, the apparent fine-tuning of our universe neither argues directly for God and the value of life, nor does the many-worlds counterpoint directly undercut the argument for God and render the evolution of life meaningless. Instead the design-type of argument and the many-worlds type of argument form something like a ladder of increasing abstraction in which, at each level or step, elements of both contingency and necessity emerge dialectically, and lead to the next step in the ladder. ${ }^{7}$ Why then should this be so? In short we have come upon one of the most general forms of the contingency argument hidden within the very debate over the contingency of the universe. Short of the very existence of the universe as such, the contingency represented by this 
dialectic between design and many-worlds is profoundly moving in its power to evoke the sense of the divine through the intricate structure of nature, and the existence of our universe even within a possible infinite of universes underscores the wonder and mysterious value of life and sentience as God's creation.

2. Continuous creation and evolution: can God work through "blind chance"?

Along with creation out of nothing, Christians believe that God continues to interact with the universe, creating order and life out of chaos and inanimate nature. But according to Darwinian evolution life, consciousness, and self-consciousness evolved according to the laws of variation and selection. What does this tell us about the claim that life is the creation of God and that humanity is in special relation to God, graced with what the Bible calls the image of God (the imago dei)? These are enormous questions facing us today, ones to which I can, again, only give the briefest of response.

The message modern culture too often takes from science is that life evolved entirely by "blind chance", to use Jacques Monod's famous phrase, and chance in turn is inimical to God's direct and purposeful action in the world. We might interpret the world as loved by God, life as important to God, and our lives as touched inwardly by God's redeeming grace. But God, according to Monod, could not really be at work in nature: theistic evolution - our attempt to combine biological evolution by natural selection with theism - is as impossible as a square circle. Or as Richard Dawkins puts it, if God is a watchmaker, God is a "blind watchmaker". 8 And what about the religious distinctiveness of the human species, the "image of God" which to Christians involves both our power to reason and to experience and respond to morality? According to Michael Ruse, these are not actually a genuine response on our part to truth or to transcendent values as revealed by God. Instead, we are conditioned by evolution to believe what is in fact a lie, for example that there are objective and universal values such as compassion, truth telling, or kindness, because in doing so our species survived and won the day against the other hominids hundreds of thousands of years ago. Religion is evolution's way of ensuring our survival, nothing more.

In one of the great achievements of contemporary religious scholarship, this challenge is being met. ${ }^{9}$ First the challenge of "blind" evolution and the Christian interpretation of evolution called "theistic evolution". ${ }^{10}$ Here the point is simple but profoundly important: not only is chance not inimical to God's continuous creative activity, it is a tool through which God actually creates new species. God chose to create the universe ex nihilo the way it is, giving it form and structure by choosing the laws of nature. Moreover, God continuously creates the universe in time through these very processes and consistently with their God-given laws, so that biological evolution per se is God's action in the world. In short, chance is not a block to God's will but a product of it. God creates through the interplay of chance and law, for it is precisely this interplay which characterizes the physical and biological processes that have produced life in this world as the handiwork of God. But this answers Dawkins and Ruse too! For if God is really at work in evolution not in spite of but through the chance events which characterize it, then the products of evolution, including our capacity for reason (and thus for doing science!) and for morality, are part of God's design and not just a natural byproduct of competition and survival.

Can we press the case further? I believe we can. Research is now under way which seeks to understand in more detail how the kind of chance and law operative at each level in nature shapes our understanding of divine action without assuming that God 
must violate or suspend the very laws of nature which God has created. Thus the goal is to find a non-interventionist view of divine action. The Center for Theology and the Natural Sciences and the Vatican Observatory are engaged in a ten-year research project one of whose primary ends is this specific goal. Here I will briefly suggest two of the directions in which that discussion is proceeding. ${ }^{11}$

We start with the quantum level, where chance seems to rule the day, but it is a kind of chance strikingly different from our ordinary experience. In daily life a chance event, like a car accident or a change in the weather, is really just an unforeseen encounter - predictable in principle but surprising in practice. Quantum physics goes much further than that. The Heisenberg Uncertainty Principle to many interpreters suggests that nature is not a closed causal system; instead it is intrinsically open to genuine novelty. Moreover, rather than being reducible to a mere collection of sharply localized atomic events, quantum physics points to a more holistic and interconnected character lying subtly within nature's outward form. Now quantum physics is subject to other interpretations besides this one, but I believe a very strong case can be made for viewing indeterminism as a feature of nature and not just an indication of our ignorance of underlying causes. ${ }^{12}$ This in turn sheds light on the question of how it is possible for us to act freely in the world, for if everything is predetermined by physics, our experience of making choices and acting on them would seem impossible, a mere psychological illusion. This is not meant to reduce mind to matter nor to claim that quantum physics can provide a complete explanation of human free will, but merely to say that the move from a closed mechanistic universe to an open quantum universe makes human agency potentially intelligible.

According to this point of view, then, science itself tells us that there can never be a complete scientific explanation of just why specific quantum events happen as they do, nor will any future theory that may replace quantum physics. Nature is intrinsically open, ontologically indeterminate, authentically spontaneous. Given this, many scholars $^{13}$ have argued that we can now conceive of God as free to act in nature without violating the laws of nature, since it is precisely these laws which leave nature open to God's action - and, once again, it is precisely these laws which God has created in creating the world as it is. Thus when a quantum event occurs, it occurs by God's direct will acting together with nature. In short, if quantum physics points not just to epistemic gaps in our theory which may some day be filled, but to ontological "bubbles" in the fabric of nature, then one is free to stipulate that God acts immediately in nature - and not just through secondary, instrumental, or natural causes. God may indeed work at higher levels in nature as well, including human experience of God's presence and will during prayer and meditation, and in community and society, and these levels would correspond in turn to psychology, neurophysiology, and so on. In doing so, God may act in a "top-down" way, but at least in this perspective, God can act in a "bottom-up" way as well to influence the future course of the world through the openness of quantum reality. Moreover, God does not act unilaterally at the quantum level. Rather God cooperates with the efficacy of nature and its openness to novelty. Whether we adopt a generic view of this "double agency" or follow the lead of process metaphysics, in which God, the past, and the intrinsic novelty of an actual occasion act together, the view made possible by quantum indeterminism is that the future is genuinely open at even the most elementary levels of the natural world.

Next we move to evolutionary biology. What is particularly important about the preceding argument is that it "cashes out" the promissory note of theists that we can conceive of God as acting not just through physics but also through the biological 
processes of variation and selection. ${ }^{14}$ To see this, we must turn to the level of the chromosome and its genetic structure. We find ourselves in a realm small enough to be affected directly by quantum processes single-gene or "point" mutations can be induced by radiation and this takes place quantum mechanically - and yet a realm whose effects extend to the entire macro sphere when genes are replicated and expressed in organisms and progeny. This means that the evolutionary history we describe scientifically through neo-Darwinian synthesis can be viewed theologically as the means by which God creates biological complexity and life. What Monod calls "blind chance" - biological variation in the form of random genetics coupled randomly to random environmental changes - can be seen as God's hidden agency - events chosen to occur by God at the genetic level to coordinate with environmental change anticipated by God, and thus chosen because of their potential value in achieving God's purposes in the evolution of life.

At the same time, Christians must be much more forthcoming about the real problems and challenges of evolution. Probably the toughest one to resolve is that life evolves through the process of death, disease, and suffering. Clearly, the domain of evolution extends the achingly poignant plight of Job to the vast landscape of nature "red in tooth and claw" over billions of years. But we certainly do not want to say that God works through evolution if that means blaming God for this suffering and death. One alternative is to view the limitations on God's power to determine the future, whether self-imposed as in John Polkinghorne's "free process defense" 15 or by metaphysical necessity as in process theology. These are important strategies, but they incur significant problems in turn. In my opinion, a more fruitful way forward is to expand the theological discussion of evolution to include not only a doctrine of creation, as we have done so far, but also the theology of redemption, as we see in the writings of Trinitarian theologians such as Moltmann and Pannenberg. If we are to avoid a simple rationalization of such prodigious suffering (lest we take the role of Job's accusers) we must seek to incorporate our theology of creation within our theology of redemption. Here the pain, disease, and death which pervade evolution are part of, and taken up ultimately within, the victory of God's over-arching redemptive purposes. Somehow the cross of Christ, on which Christians find all innocent suffering to be borne and transformed into immortal joy, must hold a clue to God's purpose in creating life via death and eternal life by redemptive suffering. I believe we must include all of nature - meaning ultimately all of the universe - within the scope of God's redemption. As Saint Paul writes to the church in Rome, all of creation is groaning for liberation. I take this to be the true challenge of evolution to Christian faith and life, for this brings us to a final question which may be the hardest to address: can Christ be seen, not only in the context of humanity and evolutionary biology, but even for the universe as a whole, the ultimate domain of creation, redemption, and sanctification?

\section{Concluding comments}

In this paper I have attempted to describe in some detail how recent developments in cosmology, physics, and evolution are moving the science religion conversation forward within the Christian community. This discussion included two key theological topics in light of contemporary science. In each case, these topics can, I believe, be given a creative new reformulation through the engagement with science. Still there are a number of pivotal issues challenging the dialogue between Christian theology and science. These issues concern the implicit assumptions made either in theology or in science, that have to be tackled if the dialogue is to grow beyond its present 
elementary stages. I hope this paper will in some modest way contribute to the broader Hindu-Christian dialogue, especially as together we face the challenges and the opportunities for religious understanding in light of contemporary natural science.

\section{Notes}

1. See Julian Chela-Flores, "The Phenomenon of the Eucaryotic Cell" (to be published in the proceedings from the Lake Como conference).

2. This section is based in part on an earlier paper which was published as "Cosmology from Alpha to Omega" in Zygon: Journal of Religion \& Science 29/4 (December, 1994), p. 557-577.

3. For a helpful survey, see John Leslie, Universes (London: Routledge, 1989); for a detailed introduction see John D. Barrow and Frank J. Tipler, The Anthropic Cosmological Principle (Oxford: Clarendon Press, 1986).

4 See W. R. Stoeger, "Contemporary Physics and the Ontological Status of the Laws of Nature", and G. F. R. Ellis, "The theology of the Anthropic Principle', both in Robert John Russell, Nancey Murphy, and C. J. Isham (Eds.), Quantum Cosmology and the Laws of Nature, Vatican City: Vatican Observatory Publications and Berkeley: Center for Theology and the Natural Sciences, 1993.

5. For a sophisticated version which clearly recognizes these problems see G. F. R. Ellis, "The Theology of the Anthropic Principle", and N. Murphy, "Evidence of Design in the Fine-Tuning of the Universe", in Russell, et. al., Quantum Cosmology and the Laws of Nature.

6. For details see Robert John Russell, "Cosmology, Creation and Contingency," in Ted Peters (Ed.), Cosmos as Creation: Theology and Science in Consonance, Nashville: Abingdon Press, 1989, pp. 177209.

7. Indeed even the ladder shows these characteristics: will it continue forever or will it end at, say, the third, or the fourteenth, or some other finite rung? Here again we have the question of design at the highest level of abstraction: why is there such a ladder, why does it have such a structure, why is it finite? infinite? did God design it?

8. Richard Dawkins, The Blind Watchmaker, W. W. Nelson: London, 1985.

9. Unfortunately the victory has not been heard by creationists who still construct what amounts to a pseudo-science based on a literal interpretation of the Bible, all the while presupposing that science, with its insistence on chance, leads necessarily to atheism and must therefore be rejected by Christians. But this simply is not the case, although it is still not widely appreciated in the culture we live in, nor is a literal reading of Scripture authentic to the original sources of that same Scripture and the religious experience out of which it arose and to which it testifies.

10. Although theistic evolution has roots in the nineteenth century's positive response to Darwin in both Europe, England, and America, a very significant recent contribution has been made by Arthur Peacocke and by Ian Barbour. One must also include here the diverse contributions to the problem by scholars including Charles Birch, Ralph Burhoe, John Cobb, Phil Hefner, Sallie McFague, and Gerd Theissen.

11. For an overview and a working typology on divine action, see my "Introduction" in Robert John Russell, Nancey Murphy, and Arthur Peacocke (Eds.), Chaos and Complexity: Scientific Perspectives on Divine Action (Vatican City State: Vatican Observatory Publications and Berkeley, The Center for Theology and the Natural Sciences, 1995).

12. Bell's Theorem has disclosed even more clearly the underlying holistic character of quantum processes by its focus on the subtle correlations between particles which once interacted and are now widely separated in time and space. See Robert John Russell, "Quantum Physics in Philosophical and Theological Perspective", in Robert J. Russell, William R. Stoeger, and George V. Coyne (Eds.); Physics, Philosophy and Theology: A Common Quest for Understanding, Vatican City: Vatican Observatory, 1988. 
How Should Religion and Science be Creatively Related? 35

13. See for example Thomas F. Tracy, "Particular Providence and the God of the Gaps", Nancey Murphy, "Divine Action in the Natural Order: Buridan's Ass and Schroedinger's Cat", and George F. R. Ellis, "Ordinary and Extraordinary Divine Action: The Nexus of Interaction", in Robert John Russell, Nancey Murphy, and Arthur Peacocke (Eds.), Chaos and Complexity: Scientific Perspectives on Divine Action, Vatican City: Vatican Observatory Publications, 1995.
14. See articles by Nancey Murphy, George Ellis, and myself in Robert John Russell, Francisco Ayala, and William Stoeger (Eds.), Evolutionary and Molecular Biology: Scientific Perspectives on Divine Action, (forthcoming, 1997).

15. See for example John Polkinghorne, The Faith of a Physicist: Reflections of a BottomUp Thinker, The Gifford Lectures for 199394, Princeton: Princeton University Press, 1994, pp. 83-5. 